\title{
A JOINT VENTURE MODEL FOR ASSESSMENT OF PARTNER CAPABILITIES: THE CASE OF ESKOM ENTERPRISES AND THE AFRICAN POWER SECTOR
}

\author{
Y.V. Soni ${ }^{1}$ and M.O. Kachieng' ${ }^{2}$ \\ ${ }^{2}$ Department of Engineering and Technology Management \\ University of Pretoria, South Africa \\ yathin.soni@eskom.co.za, mkachienga@eng.up.ac.za
}

\begin{abstract}
This article investigates the concept of joint ventures in the international energy sector and develops a joint venture model, as a business development and assessment tool. The joint venture model presents a systematic method that relies on modern business intelligence to assess a potential business venture by using a balanced score card technique to screen potential partners, based on their technological and financial core capabilities. The model can be used by business development managers to harness the potential of joint ventures to create economic growth and sustainable business expansion. Furthermore, partnerships with local companies can help to mitigate econo-political risk, and facilitate buy-in from the national governments that are normally the primary stakeholders in the energy sector ventures (directly or indirectly). The particular case of Eskom Enterprises (Pty) Ltd, a wholly owned subsidiary of Eskom, is highlighted.
\end{abstract}

\section{OPSOMMING}

Hierdie artikel ondersoek die begrip gesamentlike onderneming in die internasionale energiesektor en ontwikkel 'n gesamentlike-onderneming-model as 'n sake-ontwikkeling- en takseermodel. Die gesamentlike-onderneming-model bied 'n stelselmatige metode wat op moderne sake-intelligensie staat maak om 'n potensiële sake-onderneming op grond van die tegnologiese en finansiële kernvermoëns daarvan te takseer deur 'n gebalanseerdepuntekaarttegniek te gebruik. Die model kan deur sake-ontwikkelingsbestuurders gebruik word om die potensiaal van gesamentlike ondernemings in te span om ekonomiese groei en volhoubare sake-uitbreiding daar te stel. Verder kan venootskappe met plaaslike maatskappye help om die ekonomiese risiko te verminder en inkoop te vergemaklik van die nasionale regerings wat gewoonlik die primêre belanghebbendes in die energiesektorondernemings is (hetsy regstreeks of onregstreeks). Die besondere geval van Eskom Enterprises (Edms) Bpk, 'n vol filiaal van Eskom, word uitgelig.

\footnotetext{
${ }^{1}$ This author was enrolled for the M Eng (Engineering Management) at the Department of Engineering and Technology Management, University of Pretoria
} 


\section{BACKGROUND}

In 1999, Eskom Enterprises (EE), the wholly owned subsidiary of Eskom was formed with the objective of ring-fencing the non-regulated business activities from the regulated business activities, and of marketing the capabilities of Eskom internationally. In doing so, EE has ventured into a number of foreign countries, primarily in Africa, but also in secondary markets such as India, South America, the Pacific Rim and the Middle East. Many of these business ventures were made possible through joint ventures with public and private sector companies in the host countries.

\section{INTRODUCTION}

It is internationally accepted that the energy sector drives industrial development, which in turn drives economic development (see Figure 1). In Africa, the energy sector is relatively underdeveloped, so the ripple effect on industry, and hence the national economy, seems relatively unprogressive, when compared with the more industrialised, so-called first-world countries.

Through socio-economic development programmes such as the New Partnership for Africa's Development (Nepad), EE enjoys both economic and political support from participating African nations in its quest to develop Africa's energy sector. However, the challenge facing $\mathrm{EE}$ is its ability to develop and sustain competitive advantage, in a globalising power market, with limited resources. One way to overcome this challenge is through collaboration with other players in this market.

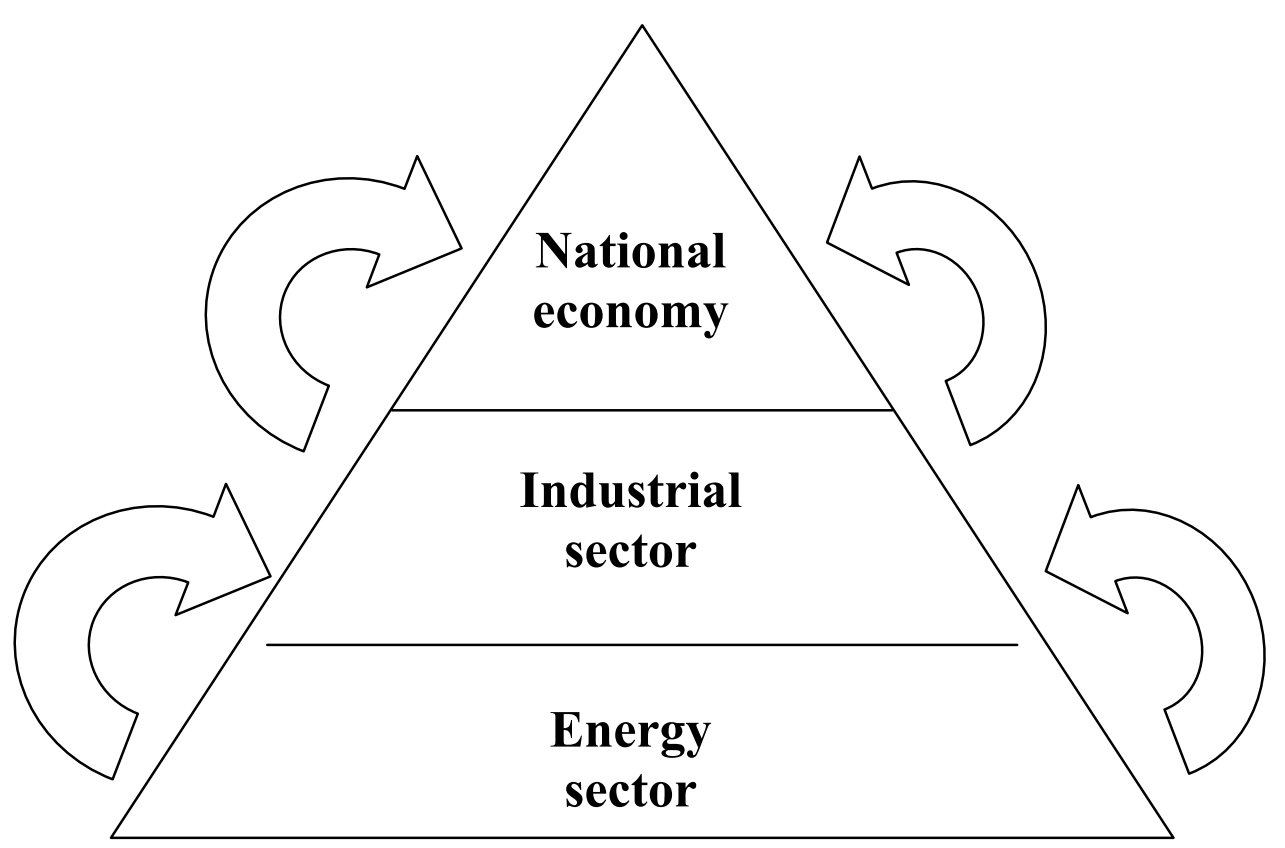

Figure 1: Stages of economic development 


\section{PROBLEM STATEMENT}

The problem facing EE is the poor track record of joint ventures, particularly those undertaken in Africa. In 2001, EE had a portfolio of 55 projects, most of which involved some type of collaboration with other companies. Only $26 \%$ of these projects have yielded a return to date, while $47 \%$ remain "in progress", and the rest have failed.

\section{THE DETERMINANTS OF A JOINT VENTURE STRATEGY}

\subsection{What are joint ventures?}

Child and Faulkner [3] define a joint venture (JV) as "a synergistic collaboration between two or more companies with different capabilities and resources, in pursuit of a common goal". A JV differs from other collaborative ventures (strategic alliances, mergers, informal cooperative agreements, etc) in that the two companies jointly form a third entity, namely the joint venture company (JVC), through which all business activities relating to the venture are managed.

There are many compelling motivators for companies to enter into JVs with other companies, such as organisational learning, risk sharing, infrastructure improvement and facilitation of global expansion of the business. According to Doz, Hamel and Prahalad [4], companies can benefit more from collaborating with each other, than from competing with each other, if they follow a simple set of four guiding principles, namely:

- Collaboration is competition in a different form.

- Harmony is not the most important measure of a partnership's success.

- Cooperation has limits. Companies must defend against "competitive compromise".

- Learning from your partners is paramount!

\subsection{The elements of business strategy}

In order to realise the benefits of JVs in a technology-based industry, partners must first take cognisance of those critical elements that shape a company's business strategy, and then identify interactions between each of these determinants in the context of their company and industry. Figure 2 illustrates the interaction between the critical elements that shape business strategy.

With reference to Figure 2, the following description is given of the elements:

- Technology strategy: This is concerned with the intentions of the company with regard to the management of its technological assets, and its integration with the overall (corporate) strategic intent, to ensure compliance and competence with some industrial benchmark.

- Financial strategy: This refers to the mechanism and policies in place to ensure the financial prosperity (profitability and sustainability) of the company.

- Human capital: This is concerned with the people a company has in its employ, and the 
capabilities made available to the company through the human skill and knowledge of these people.

- Econo-political environment: This refers to the political dynamics prevalent in a given country or region, and the reciprocal or resultant impact it has on the national economy.

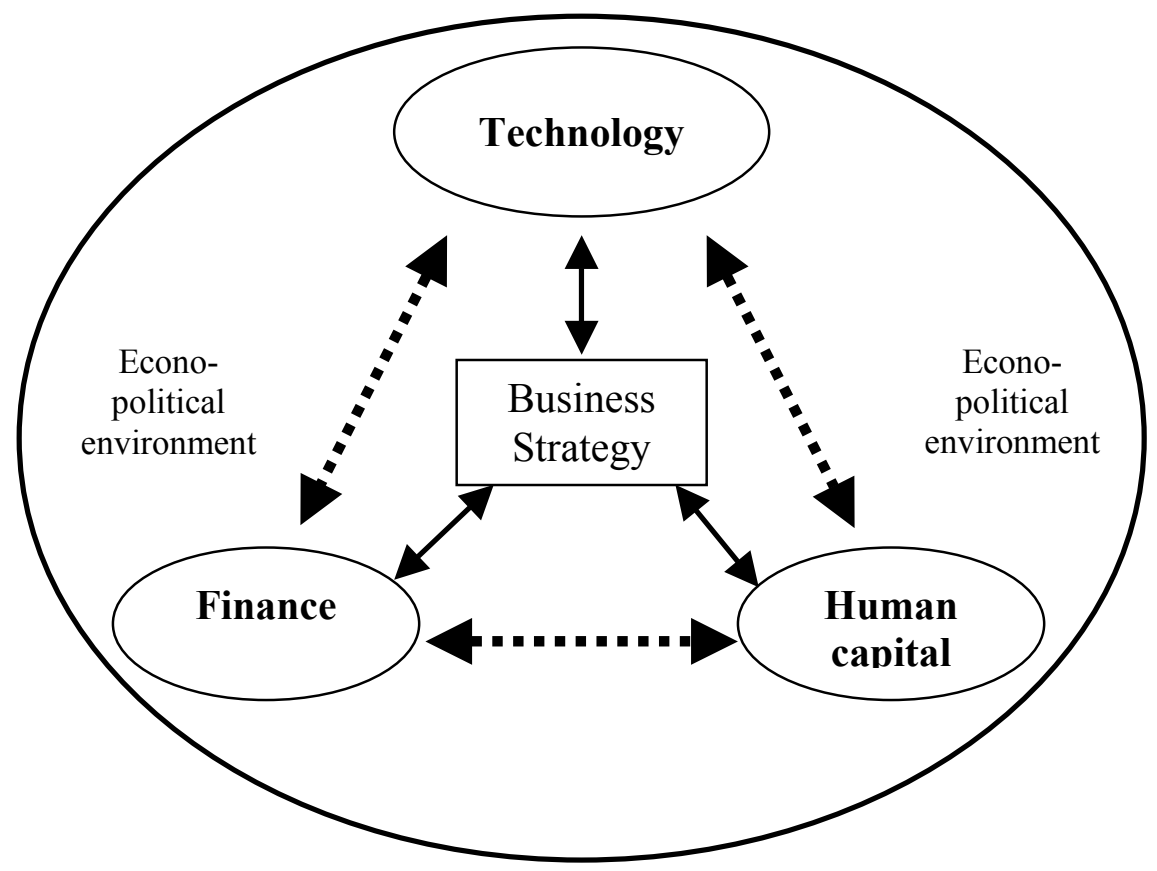

Figure 2: The determinants of business strategy

\section{Partnership capabilities: a value-added perspective}

The success of a JV clearly depends on the synergy created by the individual contributions of the partners. Good joint venture management lies not only in the execution of the project, but also incorrect partner selection. But what exactly constitutes a "good partnership"? In terms of the value chain, a good partnership is one that has the combined capability to add value through the entire spectrum of the JVC's primary and secondary business activities. The electricity sector value chain is illustrated in Figure 3, showing the primary and secondary business activities associated with the management of a large power utility (such as Eskom).

By mapping the capabilities displayed by a potential partner against each of the cells (activities) in the value chain, the venture development manager can gain a holistic view of the joint capabilities of the partnership or consortium, and identify capability gaps.

\section{ALIGNING THE TECHNO-FINANCIAL STRATEGIES OF PARTNERS}

It was illustrated in Figure 2 that business strategy is shaped by four main elements, namely technology, finance, human capital and the econo-political environment. Of these, technology and finance are of paramount importance to the strategic direction of companies within a technology-based industry, such as the power sector. Hence, only the techno-financial determinants of business strategy as well as the econo-political screening should be considered in the development of the joint venture model (JVM). The "human capital" 
element should be downplayed.

\subsection{Technology strategy}

Central to the management of a technology-based organisation (such as Eskom Enterprises) is the management of technology. In fact, according to Burgleman and Rosenbloom [5], technology is a resource of primary importance to modern business; as such, its management must be part of the company's overall business strategy. Furthermore, Porter [6] observed that technology is among the most prominent factors that determine the rules of competition.

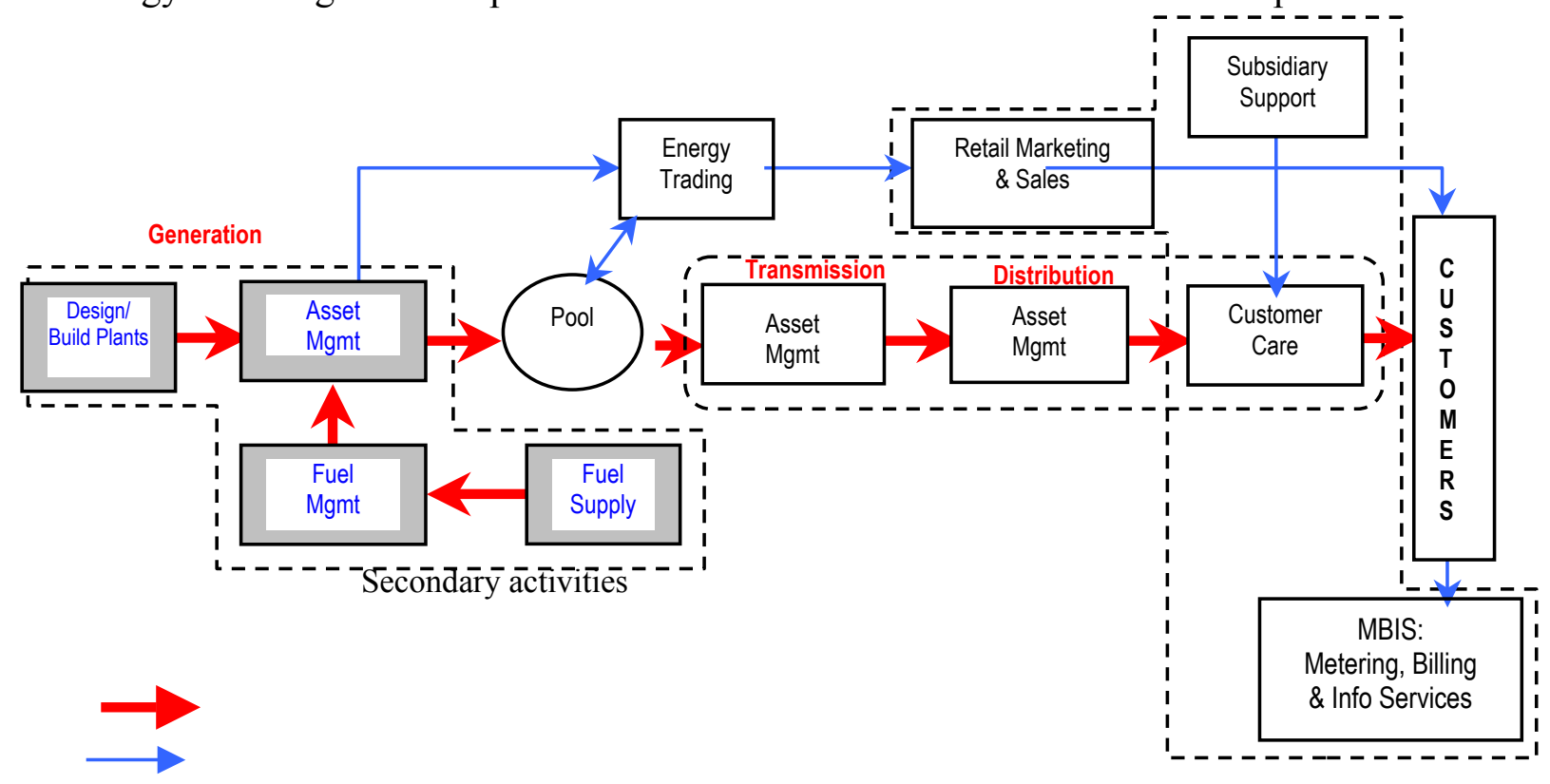

Figure 3: The electricity sector value chain

Clearly, the importance of selecting a partner with a similar technology strategy cannot be stressed enough. But how can a company practically determine the techno-strategic fit between itself and a potential partner? The first step is for each partner to understand the determinants of their company's technology strategy, in terms of the organisational and industrial contexts of the company's core technological capabilities, as well as the status of evolution of each other's core technologies, and the strategic actions to be taken in managing these assets [5]. In doing so, technological similarities and differences become more apparent, thereby enabling a clearer assessment of the techno-strategic fit between potential partners.

\subsection{Financial strategy}

The very nature of power sector development projects entails that they are characterised by relatively long payback periods and high project risk. A concession to build, own and operate a power station in Uganda, for example, may be for anything between 10 and 15 years. During this time, core technologies are evolving, and the value of money is fluctuating. Discounted cash flow (DCF) techniques, such as NPV and IRR, are most appropriate for the financial appraisal of long-term investment projects that yield constant revenues, such as annuities [7]. Non-discounted cash flow (non-DCF) techniques are unsophisticated and are not appropriate for long-term investments, due to the fact that the time value of money is 
ignored.

As far as the alignment of partners' financial strategies is concerned, there must be augmentation and synergy in their integration. For instance, EE lacks project finance ${ }^{1}$ capability due to the fact that before 1999, Eskom has dealt primarily with limited-recourse financial strategies rather than non-recourse (project) financing. Therefore EE places a high premium on attaining project finance capability through collaboration with companies that have the capabilities and the knowledge to augment the JVC's competence in this field of expertise. Other important financial capabilities include the ability to raise the required equity and debt for the venture.

\subsection{The need for a strategic fit between partners}

According to Child and Faulkner [3], there are two basic qualities that are sought after in an ideal joint venture, namely a "strategic fit" and a "cultural fit". The interaction between, and relative importance of these two qualities are best described by the strategic-fit-cultural-fit matrix shown in Figure 4.

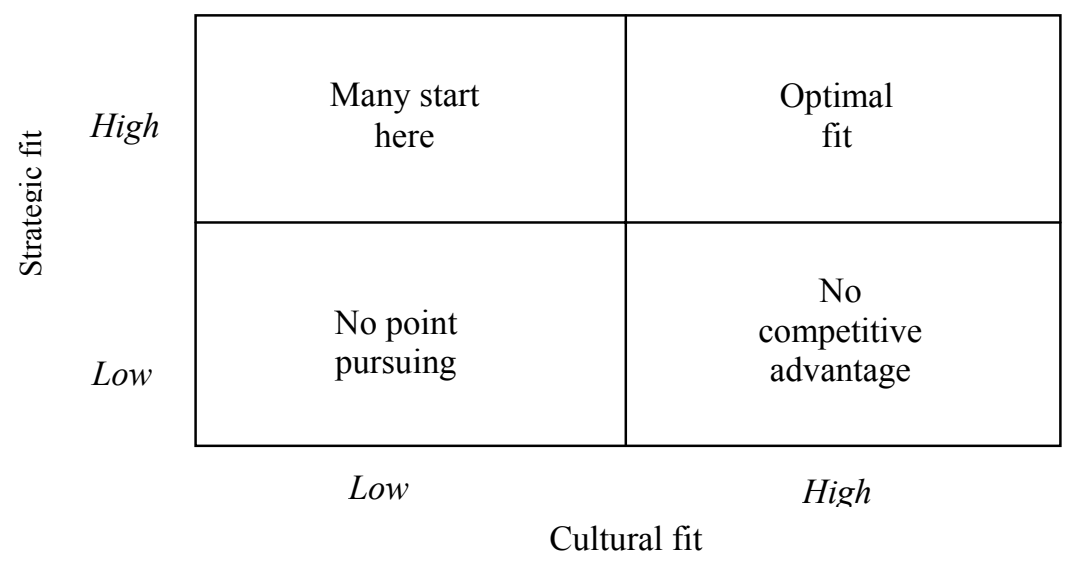

Figure 4: The strategic-fit-cultural-fit matrix

The optimal partnership is one that is categorised as being in the top-right quadrant of the matrix, where there is a good strategic and good cultural fit between the partners. If the partnership is categorised as being in the bottom-left quadrant, then there is no point in pursuing the partnership, as there is a total mismatch in both strategic intent and organisational culture.

Many partnerships begin in the top-left quadrant and progress to the top-right quadrant. A partnership that features in the bottom-right quadrant, on the other hand, may get along well, but may have conflicting strategic intents. Such a partnership boasts no competitive advantage. It is clearly evident from the above matrix that the strategic fit is more important to the sustainability and profitability of the partnership (and the business), than the cultural fit, because once the strategic fit is developed, the cultural fit can be developed over time, as the relationship matures.

\footnotetext{
${ }^{1}$ Project finance is a financial risk-reduction strategy whereby investors or lenders depend only on the revenues generated from the project for repayment of debt. No claim can be instituted against other company funds in the case of default or project failure.
} 


\section{THE JOINT VENTURE MODEL (JVM).}

The joint venture model (JVM) developed here, is based on the works of Geringer [8], who proposed that the criteria for evaluating international joint ventures can be broadly divided into task-related criteria (those that determine the viability of the venture), and partner-related criteria (those that assess the partner's capabilities). The JVM is defined in terms of these two phases, with an additional "initial screening phase" to determine whether the econo-political environment is conducive to doing business. The three phases of the JVM are illustrated in Figure 5, followed by a brief description of each phase, and how to use the model.

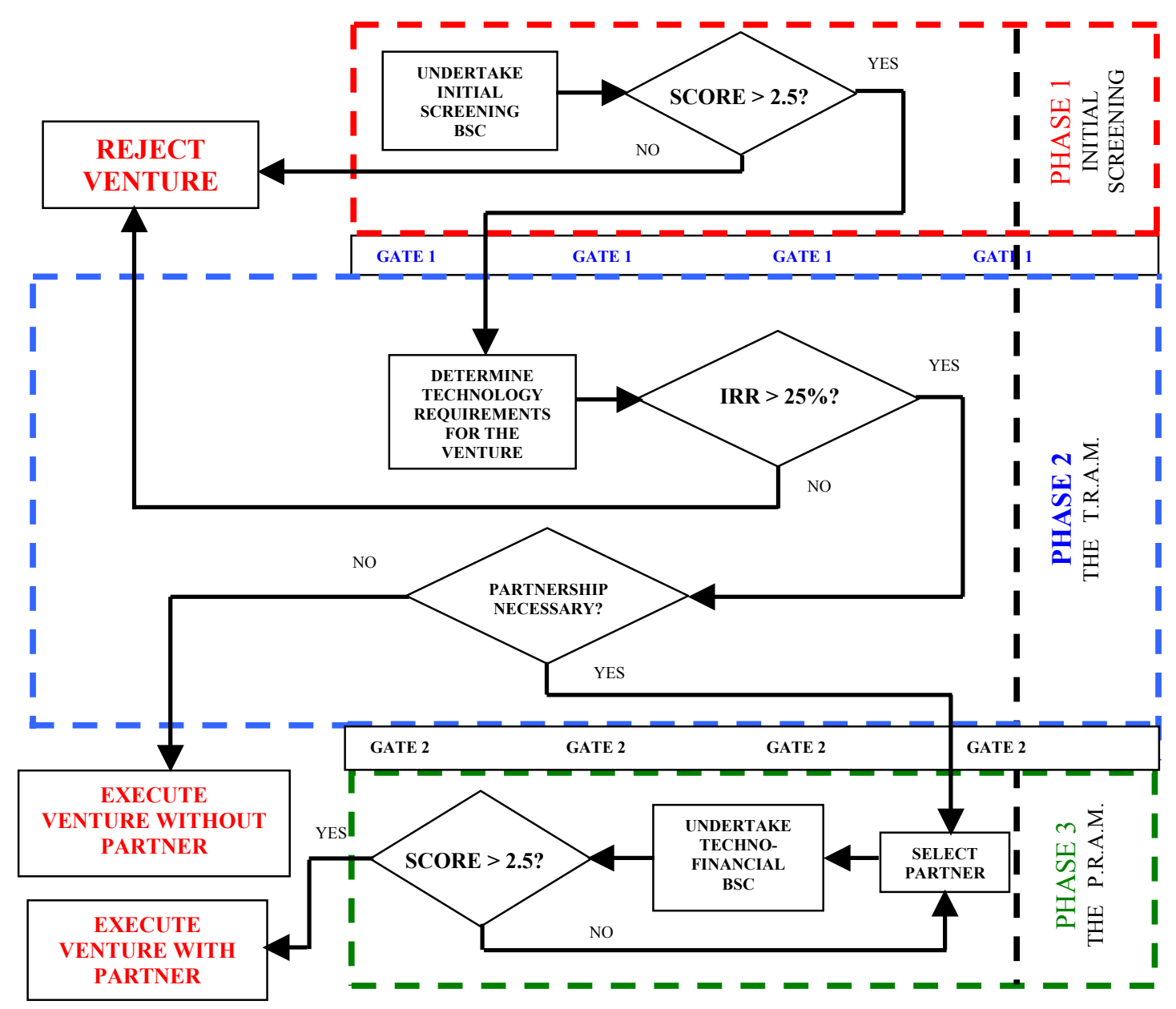

Figure 5: The comprehensive joint venture model (JVM)

\section{PHASE 1: Initial screening of the econo-political environment}

This phase of the model is concerned with testing the econo-political environment to determine whether or not it is conducive to doing business. This phase consists primarily of an initial screening balanced score card (BSC), comprising six essential criteria pertaining to the economic and political status of a country, with each criterion weighted according to its perceived importance (Figure 6). The weightings were determined by means of an audit questionnaire, which was completed by EE's business development managers. 
The results of the survey showed that "market potential" was rated as being the most important, while the "impact on the local economy" (of the host country) ranked last. Each criterion is scored on a scale of 1-5. If the total score (sum of all six scores multiplied by their relative weightings) is less than 2.5 , then the venture is rejected. If the total score is 2.5 or more, the venture qualifies for the next phase of the JVM, namely "Phase 2".

\begin{tabular}{|l|c|c|c|}
\hline \multicolumn{1}{|c|}{ Criterion } & Score (1-5) & Weighting & Value \\
\hline 1. Market potential & 3 & 0.270 & 0.81 \\
\hline 2. Business profitability and sustainability & 3 & 0.222 & 0.666 \\
\hline 3. Political stability & 2 & 0.180 & 0.36 \\
\hline 4. Buy-in from stakeholders (eg. NEPAD) & 4 & 0.122 & 0.488 \\
\hline 5. Government interest/participation & 4 & 0.111 & 0.444 \\
\hline 6. Positive impact on economy & 3 & 0.095 & 0.285 \\
\hline \multicolumn{2}{|c|}{ TOTAL VALUE } & & $\mathbf{3 . 0 5}$ \\
\hline
\end{tabular}

Figure 6. The initial screening balanced score card (BSC)

\section{PHASE 2: The task-related assessment model (TRAM).}

The two main objectives of this phase are to determine the envisaged profitability of the venture over its life, and the techno-financial capabilities required to realise this goal. In other words, this part of the JVM is concerned with what is required to make the joint venture a business success, regardless of the company structure, partner capabilities, etc.

The TRAM is primarily concerned with the internal rate of return (IRR) that the project will yield over its life, and whether this IRR is at least equal to the organisational benchmark of $25 \%$. It then becomes a question of what technological and financial (investment) requirements are needed to achieve this IRR. Also, the variables in the business case are adjusted to take the project risk into account, and the optimal business scenario is chosen. Based on these findings, the question arises whether a joint venture is necessary, or whether EE could accomplish this venture alone. If a joint venture is deemed necessary, "Gate 2" is opened, and the next phase is initiated, otherwise the venture is executed alone (i.e. no partnership is required).

\section{PHASE 3: The partner-related assessment model (PRAM)}

The objective of the PRAM is to allow the venture development manager to select a capable partner for a particular venture (once it is deemed feasible and necessary by Phases $1 \& 2$ ). This is done by first nominating a potential partner (perhaps from a particular strategic group), and then screening the partner, based on its techno-financial capabilities, once again using a balanced score card (BSC). In this case, the techno-financial BSC (Figure 7) consists of three technology screening criteria and three financial screening criteria, each weighted as before, based on the findings of an intra-departmental audit questionnaire. 
The results of this questionnaire showed that the "relevance of the partner's core technologies" ranked highest, while the partner's ability to raise debt was the least important. If a score of less than 2.5 is attained then the partner's capabilities are deemed to be inadequate to successfully execute the business venture, and another partner is nominated and screened.

\begin{tabular}{|l|c|c|c|}
\hline Criterion & Score (1-5) & Weighting & Value \\
\hline 1. Relevance of core technologies to venture & 4 & 0.218 & 0.872 \\
\hline 2. Technology acquisition and management & 3 & 0.208 & 0.624 \\
\hline 3. Project planning and management & 3 & 0.170 & 0.51 \\
\hline 4. Non-recourse finance skills & 2 & 0.154 & 0.308 \\
\hline 5. Ability to provide the required equity & 3 & 0.154 & 0.462 \\
\hline 6. Ability to raise debt & 3 & 0.096 & 0.288 \\
\hline \multicolumn{4}{|c}{ TOTAL VALUE } \\
\hline
\end{tabular}

Figure 7: The techno-financial balanced score card (BSC)

\section{CONCLUSION}

Joint ventures undertaken in technology-based industries, such as the power sector, are costeffective alternatives to out-laying fixed costs in acquiring new capabilities. By integrating their individual capabilities and resources, companies can benefit more from cooperative strategies than from all-out competitive strategies that are limited in their profitability and sustainability. This understanding is the basis for cooperation. Furthermore, partnerships with local companies can help to mitigate econo-political risk, and facilitate buy-in from the national governments that are normally the primary stakeholders in the energy sector ventures (directly or indirectly).

Success in JVs require acknowledgement of the strategic and cultural issues that influence the partnership. The capability perspective of joint ventures is useful in determining what a company can and cannot accomplish by itself for a given venture. The JVM presents a systematic method that relies on modern business intelligence to assess a potential business venture, and to screen potential partners, based on their technological and financial core capabilities, using a balanced score card technique. The model is a robust tool that can be used by business development managers to harness the potential of joint ventures to create economic growth and sustainable business expansion. 


\section{REFERENCES}

[1] Gomes-Casseres, B: Joint ventures in the face of global competition. Sloan Management Review, Spring 1989: pp17-26.

[2] Reich, R.B \& Mankin, E.D: Joint ventures with Japan give away our future. Harvard Business Review, March-April 1986, pp 78-86.

[3] Child, J. and Faulkner, D: Strategies of Cooperation: Managing alliances, networks and joint ventures. Oxford University Press, 1998.

[4] Doz, Hamel \& Prahalad: Collaborate with your competitors - and win. Harvard Business Review, January 1989.

[5] Burgelman, R.A. et al (1989): Technology Strategy: An evolutionary Process Perspective. Research on Technological Innovation, Management and Policy №4, 1989.

[6] Porter, M.E: Competitive Advantage. Free Press, New York, 1985.

[7] Gitman, L.J: Principles of Managerial Finance. Addison Wesley Longman, pp 374430, 2000.

[8] Geringer, J.M: Strategic determinants of partner selection criteria in international joint ventures. Doctoral thesis. University of Washington, 1990. 